\title{
PKM KELOMPOK KULINER KECAMATAN PINELENG KABUPATEN MINAHASA
}

\author{
Ferdinan Ivan Sangkop \\ Fakultas Teknik Universitas Negeri Manado \\ E-mail: ivan.sangkop@unima.ac.id
}

\begin{abstract}
The rapid development of technology has affected people's lifestyles where the use of smartphones and online access have become a part of everyday life. The use of technology in the business sector, especially culinary business has begun to be applied by business people and utilized by consumers. Pineleng sub-district as one of the sub-districts in the Minahasa district has many small and medium-sized culinary businesses. One of them is Samsuri Catering, which provides food orders to homes or events. Given its location in the aisle of Pineleng I and still using traditional advertisements through word of mouth, it is rather difficult to market its culinary products. For this reason, community service will be carried out by using existing competencies in information technology to develop business from partners in Pineleng District. With analysis and design in accordance with the culinary products offered, it is proposed to develop a site for online marketing that can be accessed by the wider community and is expected to develop the culinary business owned by partners.
\end{abstract}

Keywords: Online Marketing, Website, Culinary Business 


\section{PENDAHULUAN}

Dewasa ini perkembangan teknologi di dunia semakin pesat, khususnya kemajuan di bidang teknologi informasi. Hampir segala bidang menggunakan bantuan teknologi komputer yang dikembangkan dalam bentuk sistem informasi maupun jenis yang lainnya. Bidang usaha kuliner juga telah menggunakan teknologi informasi untuk pemasaran produk-produk kuliner dengan menyediakan informasi memadai yang dapat diakses oleh masyarakat luas. Akan tetapi belum semua usaha kuliner mampu memanfaatkan teknologi informasi untuk mengembangkan usahanya. Katering Samsuri adalah salah satu usaha kuliner di Kecamatan Pineleng yang telah berdiri selama 2 tahun dan sejauh ini memasarkan produknya melalui promosi secara langsung dari mulut ke mulut atau iklan tradisional berupa media cetak seperti selebaran atau brosur. Katering Samsuri didirikan oleh Bapak Samsuri dan menawarkan produk makanan yang dapat dipesan untuk diantar ke rumah-rumah ataupun acara. Tersedia juga menu Katering harian atau mingguan yang dapat dipesan dengan menu berbeda setiap harinya. Usaha Katering Samsuri dijalankan dari rumahnya yang sederhana di Pineleng I. Perkembangan usahanya dalam 6 bulan terakhir cenderung menurun karena tidak dapat menjangkau konsumen yang lebih luas dikarenakan oleh kurangnya promosi dan lokasi rumah yang agak terpencil di dalam lorong di Pineleng I.

Berdasarkan analisis situasi dan wawancara yang dilakukan dengan mitra, maka permasalahan yang dihadapi oleh mitra adalah masih kurangnya metode promosi untuk menjual produk kuliner yang ditawarkan. Selain itu lokasi rumah yang cukup terpencil membuat usahanya kurang dikenal oleh masyarakat. Selama ini yang merupakan pelanggan tetap adalah warga yang tinggal di sekitar. Katering Samsuri ingin dapat lebih mengembangkan usahanya agar bisa dikenal oleh masyarakat luas sehingga dapat meningkatkan penjualan produk kulinernya.

\section{METODE PELAKSANAAN}

Pelaksanaan kegiatan pengabdian diawali dengan perencanaan lewat survey dan analisa situasi terhadap lokasi kegiatan yaitu dengan mengunjungi mitra dan mengumpulkan informasi awal terkait produk kuliner mitra. Informasi yang dikumpulkan kemudian akan dimasukkan dalam situs berbasis web dimana akan dilakukan pemilihan nama situs serta proses pembuatan situs menyesuaikan dengan kebutuhan dan analisis awal pada mitra. Dilanjutkan dengan kegiatan pelatihan kepada mitra agar dapat meningkatkan ketrampilan dalam bidang teknologi informasi terutama untuk proses pengoperasian situs berbasis web. Evaluasi terhadap kegiatan akan dilakukan oleh pelaksana dan mitra untuk mengetahui dampak produk dan pelatihan yang diberikan diikuti dengan sosialisasi produk situs mitra agar lebih dikenal masyarakat luas. Agar informasi yang terdapat dalam situs dapat selalu diperbaharui maka mitra perlu diberi akses dan fitur untuk memperbaharui data yang akan ditampilkan. Sehingga informasi yang tampil selalu terbaru dan sesuai dengan kebutuhan mitra.

\section{HASIL DAN PEMBAHASAN}

Berdasarkan hasil survey dan analisis situasi pada tahap perencanaan maka pelaksanaan kegiatan pengabdian diawali dengan melakukan diskusi dengan pemilik usaha kuliner untuk mengumpulkan informasi untuk pengembangan situs produk kuliner mitra. Berbagai informasi yang dikumpulkan antara lain profil usaha, harga dan jenis paket kuliner yang ditawarkan, lokasi, foto produk serta informasi kontak untuk pemesanan.

Produk kuliner mitra kemudian didokumentasi untuk ditampilkan dalam situs produk kuliner, proses dokumentasi dilakukan lewat konsultasi dengan mitra terkait produk apa saja yang ingin ditampilkan serta kisaran harga yang ditawarkan berdasarkan paket harian. Tidak lupa juga dilakukan pemilihan nama situs dan desain logo dengan persetujuan pemilik usaha. Berdasarkan diskusi yang dilakukan, pemilik usaha menginginkan agar situs produk mudah dioperasikan dan menampilkan informasi dengan jelas sehingga dipilihlah tampilan situs single page site dimana tampilan situs akan ditampilkan dalam 1 halaman penuh dan dibagi dalam berbagai blok berbeda untuk menampilkan informasi.

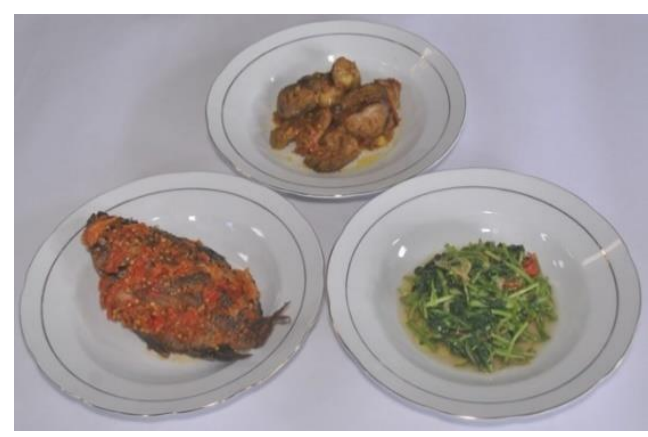

Gambar 1. Dokumentasi Produk Kuliner

Situs produk kuliner yang telah selesai dikembangkan kemudian dipublish pada hosting 
online agar dapat diakses oleh masyarakat luas. Dilanjutkan dengan kegiatan pelatihan kepada mitra agar dapat meningkatkan ketrampilan dalam bidang teknologi informasi terutama untuk proses pengoperasian situs berbasis web.

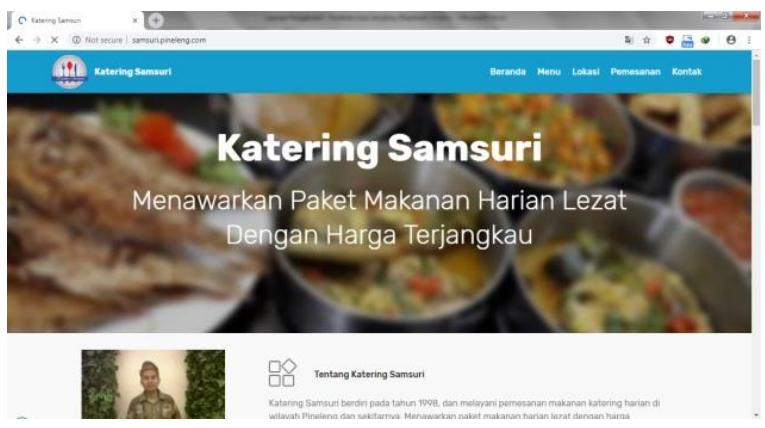

Gambar 2. Situs Kuliner Katering Samsuri

Beberapa fitur yang ditawarkan pada situs produk kuliner mitra antara lain menampilkan informasi profil usaha, informasi menu dan harga paket yang ditawarkan, testimoni pelanggan, denah lokasi serta fitur pemesanan produk secara online. Selain pelatihan kepada mitra pemiliki usaha dilakukan juga sosialisasi kepada ibu-ibu pelaku industri rumahan untuk memasarkan produk kuliner mitra serta menunjukkan dampak penggunaan informasi teknologi untuk pemasaran produk dan pengembangan usaha industri rumahan.

\section{KESIMPULAN}

Berdasarkan pelaksanaan Pengabdian Kepada Masyarakat di Kelompok Kulinet Kecamatan Minahasa Desa Pineleng Satu maka dapat ditarik beberapa kesimpulan antara lain: a. Situs berbasis web berisi informasi produk kuliner yang ditawarkan oleh mitra telah berhasil dibuat dan dapat digunakan sebagai media pemasaran online untuk membantu pengembangan usaha mitra.

b. Pelaksanaan pelatihan kepada mitra telah dilaksanakan, tentang cara penggunaan situs yang sudah dibuat untuk kemudian dijalankan dan dikelola oleh mitra.

\section{REFERENSI}

Sakur, Stendy. 2005. Aplikasi WEB Basis data dengan Dreamweaver MX 2004. Yogyakarta: Andi, 2005.

Studio, Tim Digital. 2005. Seri Pelajaran Komputer Mengoperasikan Software Web Design. Jakarta: Elex Media Komputindo, 2005.

Whitten, Jeffrey L., Bentley, Lonnie D., dan Ho, Thomas I.M., System Analysis and Design Methods, Mosby College Publishing, USA.York : McGraw-Hill, 1997.

Yuhefizar, Mooduto, HA dan Hidayat, Rahmat. 2006. Cara Mudah Membangun Website Interaktif menggunakan Content Managemen System Joomla. Jakarta: Elex Media Komputindo, 2006.

Zaki, Ali dan Community, SmitDev. 2008. 36 Menit Belajar Komputer. Jakarta: Elex Media Komputindo, 2008. 